\title{
4. PERSPECTIVES ON THE CONCEPTS OF GIFTING AND TALENT AND HOW THEY ARE USED IN THE ARTS
}

\author{
Ona Ionica Anghel ${ }^{260}$
}

\begin{abstract}
The educational programs dedicated to gifted and talented people are developed or must be developed starting with an adhesion to a definition of the working concept, in this case „giftedness" or "talent”. A foray into the literature proves that the meaning of the concept of giftedness has developed over time, as influenced by various factors such as historical (history of the research) and of human nature (psychological or educational). The aim of the paper is to make a review of the associated key moments in the evolution of the concept of giftedness. The bibliographical sources allowed us to achieve a chronological overview of the position/attitude of the most prestigious researchers in the field, who tried to explain the concept of giftedness and talent. The collected data demonstrates that there is no unanimous acceptance of a single definition until today, and that the concept keeps its tendency to perpetual transformation. The constant during this time remains its relationship with the demonstrated, respectively with the potential performance.
\end{abstract}

Key words: giftedness, talent, the concept, history

\section{Introduction}

"Giftedness”, "precocity”, “talent”, “potential performance”, "excellence", "excellent skills" are concepts whose meaning is addressed by the researchers and practitioners to the fascinating field of "giftedness" which seeking the deep understanding of the superior gifted and talented people as the engine of the civilization's evolution - could be considered as the "point 0 " of all the human activities' branches.

The fact that already in early 1900s Lewis Terman contributed to the building of one of the most common intelligence measure tests (Stanford Binet Intelligence Scale), in a time when only the objectively measurable was considered as belonging to science, it helps in recognizing the on-coming of the concept of giftedness aside the science.

The phenomenon of giftedness has a cultural significance, as being a "social construct" (Borland, 2005). The cultural nuance of the concept is actually recognized by many researchers, such as Tannenbaum, 1986, Sternberg, 2005. Borland notes that the conceptualizing of the superior giftedness and talent began just because of the need to welcome the special education needs of the gifted children. This beginning was marked by T.H. Henry's work "Classroom Problems in the Education of Gifted Children. The Nineteenth Yearbook of the National Society for the Study of Education", published in 1920 in the U.S. (Borland, 2005).

In a document of the European Commission on educational intervention measures to support all forms of excellence is expressed the tendency at

\footnotetext{
260 Lecturer PhD., “George Enescu” National University of Arts from Iaşi, Romania, email: ona_anghel@yahoo.com
} 
educational policy level of some nations (Finland, Sweden and Norway) to avoid the terms of gifted and gifted and shifting the emphasis on children's development potential. The same document specifies that the term "gifted" is used in the description of academic excellence, and the "talent" in describing excellence in sport or art (Comisia Europeană, 2006).

\section{Cornerstones in the evolution of the concept of giftedness}

The meaning of the concept has evolved under the influence of the research results, which were increasingly interested about the different aspects of giftedness and thus, over time, it has received many definitions. Monks claims that on may count four categories of definitions of the giftedness in the literature (Monks, 2005):

- two of them concern the psychological constructs (in the features and in the cognitive components oriented models);

- the third focuses on performance;

- the fourth refers on the environmental factors' influence.

The representatives of the approach centered on features consider the giftedness as a relatively stable personality feature which does not depend on the environment, the historical period or the social-economic conditions and which is equivalent to superior intelligence. The cornerstone of this approach is Terman's theory. Giftedness is related in this case to a quantity level. From this point on the individuals are placed on the two sides of an axis: normal or gifted ones.

In the second approach on giftedness, the meaning of the concept remains still in the field of quantitative specifications, but the number of areas to be expressed the high skills grows. For example, Gardner, 1983, describes 9 intelligence types, Sternberg, 1996, 3 types of successful intelligence and Gagne, 1989, 40 skill areas. Renzulli, 1978, introduces the third version of understanding the giftedness. In order to identify it, there are relevant the personal achievements and performance as evidence of a high gifted behavior, and the concept is viewed from a multidimensional approach.

The relationship between the performance potential and the achieved performance is starting to be considered. In order to design and implement training programs, it becomes important to know what factors intervene so that potential gifted behavior may become a fact. For this perspective emerges the fourth possibility of understanding the giftedness: the procedural character joins to its multidimensional one, too. Several studies concerning the evolution of the concept's meaning, its stages from the Terman's results until now, which its identity crisis are, etc. were presented more synthetic or broader to the interested public (Monks, 1993, 2005, Feldhusen, 2005, Mayer, 2005, Dai 2009, Davidson, 2009, respectively Jigau, 1994, Cretu, 1997 in the local literature). Gathering data from the available sources, we point out below the highlights in the evolution of the concept:

- 1920, Henry's „Classroom Problems in the Education of Gifted Children. The Nineteenth Yearbook of the National Society for the Study of Education” is 
the first intervention recorded in the official documents in this direction. The problem of the endowed persons is discussed publicly for the first time.

- 1925, L. Terman publishes the results of the mass measuring of the U.S. children's intelligence. By using the Stanford-Binet Intelligence Scale, he identifies 1528 children with IQs over 135, whose lives are studied in detail. These studies have shown that those children with superior results at the intelligence tests are "quite normal except for their academic superiority and their very good health" (Feldhusen, 2005, p.66). The basic idea of Terman's theory, although strongly contested, still has supporters and claims that intelligence is a genetically determined general human quality; it can be objectively measured and can predict the future performance of the beholder.

- 1936, Thurstone contributes to understanding intelligence and its role in giftedness. He reveals the existence of multiple factors of intelligence and shows that the humans have unique patterns of cognitive ability - numerical, verbal, spatial, of fluency - which are components of the general intelligence. Later, by performing an analytical research of the intelligence factors, Catella, 1971, shows that some aspects of the intelligence are genetically determined, while others are produced by the interaction between genetic inheritance and learning opportunities (Feldhusen, 2005).

- 1959, Guilford identifies hundreds of intelligence factors, by using new methods in factors' analysis. He proposes in 1971 a structure of intelligence with three dimensions: content with whom the thought operates, operations or processes of thinking and operations products (Feldhusen, 2005).

- 1952, Pritchard points out that children who "promise a high level creativity" may be considered as gifted children too (Cretu, 1997, p.33), and their identification requires something else than simply the intelligence tests.

- 1955, Passow supports the multidimensionality of the superior giftedness and suggests the overcoming of the superior intelligence's meaning by extending it to "the ability to superior preparedness in any sphere of human activity” (Passow, 1955, cited by Cretu, 1997, p. 34)

- 1958 Witty is in the same tone with Pasow and supports a broader definition of the superior giftedness, beyond the limits of the intelligence test results and recommends that "the definition of the giftedness [to] be extended and thus any child whose performance (...) are remarkable to be taken in consideration". (1958, Witty, p 68, cited by Dai, 2009, p.45). The methodology for identifying the superior gifted children is enriched by adopting tests referring to the authentic tasks in addition to the performances tests.

- 1965, Getzels and Jackson criticize the exclusive use of intelligence tests in identifying the superior giftedness. This identification ways would omit the people with high creativity who don't get a high enough IQ score, so they would be excluded from the educational programs dedicated to the gifted (Dai, 2009).

- 1972, Marland Report is the result of the recognition of the superior gifted children's rights to a differentiated education in the U.S. and the first normative document which provides a formal definition for the superior giftedness. In 
Marland Report there are considered as "children able to high performance, those identified by qualified persons as having achievements and / or potential abilities in any of the following areas, separately or in combination: 1. General intellectual ability; 2. Specific academic aptitude; 3. Creative or productive thinking; 4. Ability in leadership; 5. Talent for visual or stage arts; 6. Psychomotric skills." (Cretu, 1997, pp. 35 - 36).

- 1977, 1987, Renzulli sees the high endowment as a dynamic and multidimensional phenomenon. He develops a three-ring model of the superior giftedness which implies the synergistic cohesion of the abilities above average, task involvement and creativity. In order the three elements lead to an endowed behavior, there is need of proper environmental and personality factors. The performance proofs the existence of superior giftedness and talent. (Dai, 2009)

- 1983, 1999, Gardner argues that on may discuss about 9 types of "intelligence": logical-mathematical, verbal-linguistic, spatial, musical, kenestezic, intrapersonal, interpersonal, naturalistic and existential. The theory was immediately embraced by practitioners who have chosen it in order to identify the gifted children. (Dai, 2009, Feldhusen, 2005).

- 1996, Sternberg distinguishes, according to the triarchic theory of intelligence, between three types of (success) intelligence: analytical, creative and practical and emphasizes that the intelligence and the giftedness which are considered most frequently as universal human qualities are actually socially modeled by the reflecting beliefs and cultural values (Dai, 2009).

- 1993, Gagne comes with a new perspective in linking giftedness and talent, pointing out that although dependent, the two concepts are different. The first concept refers to "possession and use of special natural abilities (called aptitudes or gifts) in at least one field of activity", during the second designates "remarkable mastery of some knowledge and skills, which are systematically formed in at least one field of activity" (Gagne, 2005, p.99). Gagne and Feldhusen, 1992, 1999, list several talents related to the areas of human activity that can turn the potential of giftedness into performance: mathematical, musical, social, technological, artistic, athletic, vocational, etc. (Felhusen, 2005)

- 1997, C. Cretu proposes an approach of the superior giftedness and talent, refering to the concept of global success. The evaluation of giftedness will be thus holistic and integrative and will support the differentiated and individualized training both of the superior gifted students having success in the school and the superior endowed but under-achieved as well. (Cretu, 1997, Cretu, 2009)

- 1999 Schavinina, and later other authors, note the relativity of the superior giftedness in what concerns the time-factor. On the one hand the superior may manifest itself or not in different stages of life, and this happens in dependence on many factors (1999, Schavinina, cited Dai, 2009); on the other hand it may have a different meaning, depending on the age's phase of the subject (Subotnik \& Jarvin, 2005). 
- 2000, the researchers from Munich (Ziegler, Heller, Perleth) see the higher giftedness as a phenomenon in evolution which combine dynamically the personality, the environment, and the chance factors in order to determine endowed behaviors in different fields of human activity. In this way, the performativity is experienced in the adulthood (Dai, DY, 2009).

- 2003, Sternberg launches the WICS model of intelligence. WICS is an acronym for Wisdom, Intelligence, Creativity and Synthesis. "According to this model, one may be a decent contributor to the society without synthesizing the first three attributes, but never become someone really great”. (Sternberg, 2005, p.327).

- 2005, Ziegler argues that the giftedness is not a personal attribute and the human being possesses neither endowment nor talents. In this view, giftedness implies the development of a repertoire of actions in extension and an increased performance of these actions inside a field. The action repertoire is represented by all the possible actions that an individual is able to perform (Davidson, 2009).

- 2006, Ericsson claims that the superior giftedness is nothing but an expertise in a field, which may be obtained by training and diligent practice, and the genetic factors are totally excluded (Davidson, 2009).

As a summary of those key moments concerning the development of the concept of giftedness, Dai, 2009, highlights three stages: concept construction, concept deconstruction, and concept reconstruction. Dai calls essentialism the first phase, opened by the publication of Terman's research. In order to define the superior giftedness, there was relevant in this stage an essence, an unique quality as determining the behavior of endowment which was measureable at the quantitative level, this being the intelligence.

The critical reactions came from the cognitivist psychologists and sociologists, who saw this understanding of superior giftedness as reductionist, and who started the second phase, called the social-scientific emancipation. It shows that the intelligence is a more complex and abstract concept, which may not be reduced to the "G factor" (Gardner 1983, Sternberg, 2000), and it puts in question the validity of the superior gifted people's enrollment in the first $1 \%$, according to the intelligence tests results (Grinder, 1985). Moreover, there is questioned what it was attributed to the innate talent, as an explanation of the superior performance, this being in favor of the research dedicated to every area of human activity (Ericsson, 2005).

The third stage, of development, during which the concept is rebuilt, emphasizes on addressing the high giftedness as a dynamic state in which several components (personality and environmental, innate and developed factors) must intersect themselves in order to create it. Renzulli, 1977, opened a new way in this approach, which has been chosen and enriched both theoretically and practically by the scholars interested in the research of special giftedness and talent. 


\section{Conclusions}

As it happens with most of the psychological constructs, the meaning of the concept of giftedness/talent changes under the impact of the trends in social and human fields of study, or is determined by the results given by the scholars in the excellence fields.

Regardless of the historical moment in which we talk or of the focus in which we are - psychological, social or educational, the common thing in all the approaches concerning the concepts of "giftedness" and "talent" is the connection between endowment and performance. When discussing about performance, this happens on the axis of potential and fact.

In international literature most frequently, the terms "giftedness" and "talent" are used interchangeably, as synonyms, with nuances of rigor. Given that research has shown that both concepts are multidimensional, determined by both internal and external factors, by innate or educated factors, this is the way we like too. We approach the synonymous option too because both terms are used to designate the same reality: the presence or potential of a remarkably performing behavior, and if that behavior denotes technical performance, we are talking about technical talent, if it shows performance in art, we are talking about artistic talent, etc. In this situation, both talented technicians and artists are both gifted (or gifted in art or gifted in technique).

Because of its generosity, we agree the definition of giftedness given by David Yun Dai and widely accepted in research community - eg. Mayer, 2005 „gifted is demonstrated excellence by age- appropriate standards, through authentic, exceptional performance or potential for excellence, demonstrated through aptitude tests, interviews, and clinical observations of behavior and performance” (Dai, 2009, p. 41).

Aknowledgements: This paper is part of my doctoral thesis named Educational Policies and Strategies to Support and Promote the Talent in Technical Domains. I wish to express my gratitude to my scientific coordinator, Ph.D. Creţu Carmen, for mastery with which she guided me in my research.

\section{Bibliography}

1. Borland, J., 2005, Gifted education without gifted children, în Sternberg, R., S., Davidson, J., E., (Eds.), Conception of Giftedness, Second Edition, Cambridge University Press, 1-19.

2. Comisia Europeană, 2006, Măsuri educaţionale specifice pentru promovarea tuturor formelor de excelenţă în şcolile din Europa, http://www.giftededu.org/resources/Eurydice-Excelenta-in-Scolile-din-Europa.pdf

3. Creţu, C. ,1997, Psihopedagogia succesului, Ed. Polirom, Iaşi.

4. Dai, Y., D., 2009, Essential Tensions Surrounding the concept of Giftedness. în Shavinina, L., V. (Eds.) International Handbook on Giftedness, Springer Science + Business Media B.V., $39-80$. 
5. Davidson, J., 2009, Contemporary Models of Giftedness, in Shavinina, L., V., (Eds.) International Handbook on Giftedness, Springer Science + Business Media B.V., 81 - 97.

6. Ericsson, K., A., 2009, An Expert Performance Approach to the Study of Giftedness, în Shavinina, L., V., (Eds.) International Handbook on Giftedness, Springer Science + Business Media B.V., 129 - 154 .

7. Feldhusen, J., 2005, Giftedness, Talent, Expertise and Creative Achievement, in Sternberg, R., S., Davidson, J., E., (Eds.), Conception of Giftedness, Second Edition, Cambridge University Press., 65 - 79.

8. Gagne, F., 2009, Debating Giftedness: Pronat vs. Antinat, în LV. Shavinina (Ed.), International Handbook on Giftedness, Springer Science + Business Media B.V., 115 - 198.

9. Jigău, M., 1994, Copiii supradotați, Ed. Ştiință și Tehnică, București.

10. Mayer, 2005, The Scientific Study of Giftedness, în Sternberg, R., S., Davidson, J., E., Conception of Giftedness, Second Edition, Cambridge University Press., 436 - 447.

11. Mönks, F.J. \& Mason, E.J., 1993, Developmental Theories and Giftedness, in K.A. Heller, F.J. Monks \& A.H. Passow (Eds.), International Handbook of Research and Development of Giftedness and Talent, Oxford: Pergamon Press Ltd.

12. Mönks F., Katzko, M., W., 2005, Giftedness and Gifted Education, în Sternberg, R., S., Davidson, J., E. (Eds.) Conception of Giftedness, Second Edition, Cambridge University Press., 187 - 200.

13. Sternberg, R., J. ,1993, Procedures for Identifying Intelectual Potential in the Gifted: A Perspective on Alternative "Metaphors of Mind", in K.A. Heller, F.J. Monks \& A.H. Passow (Eds.), International Handbook of Research and Development of Giftedness and Talent, Oxford: Pergamon Press Ltd., 185 - 208. 14. Sternberg, R., J., 2000, Successful Inteligence: a Unified View of Giftedness, în Van Lieshout, C., F., M., \& P.G., Heymans, Developing Talent Across The Life Span, Philadelphia, Psychology Press, Taylor and Francis., 4366.

15. Subotnik, R., Jarvin, L., 2005, Beyond Expertise - Conceptions of Giftedness as Great Performance, în Sternberg, R., S., Davidson, J., E. (Eds.) Conception of Giftedness, Second Edition, Cambridge University Press, 343357.

16. Ziegler, A., 2005, The Actiotope Model of Giftedness, în Sternberg, R., S., Davidson, J., E. (Eds.) Conception of Giftedness, Second Edition, Cambridge University Press. 411 - 436. 